\title{
Endovascular treatment of late complications of open surgical repair in abdominal aortic and iliac segment
}

\author{
Piotr Szopiński', 2, Eliza Pleban', Maciej Stryga', Piotr Ciostek ${ }^{2}$ \\ 'Clinic of Vascular Surgery, Institute of Haematology and Transfusion Medicine, Warsaw, Poland \\ ${ }^{2} I^{\text {st }}$ Chair and Clinic of General and Vascular Surgery $2^{\text {nd }}$ Faculty of Medicine Medical University of Warsaw, Poland
}

\begin{abstract}
Introduction. Promising results of endovascular abdominal aortic aneurysm treatment prompts one to consider applying the method in order to manage complications following the previous open procedures in the aorto-iliac segment. The study aimed at assessing the technical feasibility of applying endovascular methods to manage complications in this group.

Material and methods. From December 2009 to August 2018, 26 patients (24 males, 2 females) with a mean age of 72 years, underwent endovascular procedures as reinterventions to manage paraanastomotic aneurysms and new true aneurysms in aorto-iliac segment. Twenty one bifurcated, two branched devices and five tube stent-grafts have been implanted.

Results. One immediate open conversion was performed. Eventually, in all of the analysed cases, perianastomotic pseudoaneurysms and true aneurysms were successfully managed. Two cases of type I endoleaks were noticed and managed intraoperatively. No deaths occurred in the perioperative period. In six patients, there were early local complications and early general complications were reported in eight patients. The average length of hospital stay was seven days. Patients have been followed up for 6 to 90 months. No endoleaks nor stent-graft migrations have been reported. Five deaths have been noted not connected with the secondary intervention. Sixteen patients remain in follow-up.
\end{abstract}

Conclusions. Endovascular perianastomotic aneurysm treatment is technically feasible and associated with a low risk of perioperative complications, and a high surgical efficacy. When planning the reintervention, one should take into account the altered anatomy of the aorto-iliac segment. Familiarity with the equipment and experience in the endovascular techniques is of crucial significance.

Key words: complications, endovascular treatment, stent-graft

Acta Angiol 2018; 24, 4: 123-133

\section{Introduction}

Abdominal aortic reconstructive surgeries are routine procedures performed in numerous vascular surgery centres. Despite the mastery of the surgical technique, though, the procedures are not free of serious late complications, with periprosthetic pseu- doaneurysms being the most common. It is estimated that this complication affects $0.5 \%$ to $15 \%$ of the surgically managed patients [I]. True aneurysms which are formed within the aorta, above or below the implanted vascular grafts, also constitute a significant problem. Surgical reintervention is complicated and associated with a high perioperative risk. The mortality rate is

Address for correspondence: Eliza Pleban, Clinic of Vascular Surgery, Institute of Haematology and Transfusion Medicine, Indury Gandhi 14, 02-776 Warsaw, Poland, e-mail: proteasom@poczta.onet.pl 
$17 \%$ for patients undergoing elective surgery and ranges from $66 \%$ to $100 \%$ in urgent operations [2]. Promising results of endovascular primary abdominal aortic aneurysm treatment prompts one to consider applying the method in order to manage complications following the previous open procedures.

The study aimed at assessing the technical feasibility of applying endovascular methods to manage complications in patients who had undergone conventional repair procedures involving the aorto-iliac segment.

\section{Material and methods}

From December 2009 to August 2018, 26 patients underwent endovascular procedures as reinterventions to manage para-anastomotic aneurysms and new true aneu- rysms in aorto-iliac segment. The analysed group included 24 males and two females. The patients' age ranged from 60 to 82 (mean 72 years). Nineteen of the patients had undergone primary implantation of a tube aortic graft. One patient had been treated with an ilio-femoral graft, and in the remaining patients bifurcated bypass grafts had been sutured, including two aorto-bi-iliac grafts and three aorto-bifemoral grafts. In one of the bifurcated grafts, one limb of the vascular graft was sutured to the common iliac artery and the other limb to the common femoral artery. In 18 patients, the end-to-end proximal anastomosis was performed, while in the other six the end-to-side method was used. The iliofemoral graft was anastomosed endto-side (Table I). Pseudoaneurysms dominated amongst the causes behind endovascular reoperation, with 14 of them located at the level of proximal, and seven at the

Table I. Patients' characteristics. Indications for primary operation and prosthesis used (note the same order of patients in all Tables)

\begin{tabular}{|c|c|c|c|c|}
\hline $\begin{array}{l}\text { Pt } \\
\text { no. }\end{array}$ & Sex & $\begin{array}{l}\text { Age at the time of } \\
\text { secondary intervention }\end{array}$ & Indications for promary open repair & Primary prosthesis \\
\hline 1 & M & 73 & AAA & Tube prosthesis \\
\hline 2 & $M$ & 70 & Ruptured AAA & Bifurcated (aorto-bi-iliac) prosthesis \\
\hline 3 & M & 80 & AAA & Tube prosthesis \\
\hline 4 & M & 73 & AAA & Tube prosthesis \\
\hline 5 & $\mathrm{~F}$ & 61 & Aortoiliac occlusion & Bifurcated (aorto-bi-femoral) prosthesis \\
\hline 6 & M & 70 & AAA & Tube prosthesis \\
\hline 7 & M & 72 & AAA & Tube prosthesis \\
\hline 8 & M & 75 & AAA & Tube prosthesis \\
\hline 9 & M & 72 & AAA & Tube prosthesis \\
\hline 10 & M & 73 & $\mathrm{AAA}$ & Tube prosthesis \\
\hline 11 & M & 64 & AAA & Tube prosthesis \\
\hline 12 & M & 70 & Aortoiliac occlusion & Bifurcated (aorto-bi-iliac) prosthesis \\
\hline 13 & M & 82 & AAA & Tube prosthesis \\
\hline 14 & M & 75 & $\begin{array}{l}\text { AAA, bilateral aneurysms of CIA, } \\
\text { aneurysm of the left CFA }\end{array}$ & Bifurcated (aorto-ilio-femoral) prosthesis \\
\hline 15 & M & 72 & AAA & Tube prosthesis \\
\hline 16 & M & 67 & AAA & Tube prosthesis \\
\hline 17 & M & 80 & CIA and EIA occlusion (right side) & Ilio-femoral graft (right side) \\
\hline 18 & M & 76 & AAA & Tube prosthesis \\
\hline 19 & M & 74 & AAA & Tube prosthesis \\
\hline 20 & M & 60 & Aortoiliac occlusion & Bifurcated (aorto-bi-femoral) prosthesis \\
\hline 21 & M & 79 & AAA & Tube prosthesis \\
\hline 22 & M & 63 & AAA & Bifurcated (aorto-bi-iliac) prosthesis \\
\hline 23 & $\mathrm{~F}$ & 72 & AAA & Tube prosthesis \\
\hline 24 & M & 80 & AAA & Tube prosthesis \\
\hline 25 & M & 76 & AAA & Tube prosthesis \\
\hline 26 & M & 64 & AAA & Tube prosthesis \\
\hline
\end{tabular}

AAA: abdominal aortic aneurysm, CIA: common iliac artery, EIA: external iliac artery, CFA: common femoral artery 
distal anastomosis. In one of the patients, pseudoaneurysms were found at both anastomotic sites. Fifteen para-anastomotic true aneurysms were also reported, two of which were formed above the proximal anastomosis. One aneurysm involved the infrarenal segment of the abdominal aorta, one above the proximal anastomosis, and in one case a thoracoabdominal aneurysm was found. In eight cases, the true aneurysms were located in common iliac arteries. Pseudoaneurysms coexisted with true aneurysms in five patients. Before the procedures, all patients underwent CTA examinations. The vessel and graft anatomy and the morphology of the newly formed aneurysms were assessed (Table 2). Before designing the endovascular stent-graft, the following elements were analysed: the maximum diameter of the anastomotic aneurysms, the length, diameter and angulation of the aneurysm neck, the length and diameter of primary graft primary graft, the length, diameter and tortuosity of the common, external and internal iliac arteries, and finally the distance from the lower renal artery to the aortic bifurcation or to the graft bifurcation. The endovascular procedures were performed with the use of Pulsera BV (Philips) and Artis Zee (Siemens) angiographs. As a postoperative antithrombotic prophylactic treatment, subcutaneous enoxaparin was administered once or twice daily, with the doses dependent on the body mass, and $75 \mathrm{mg}$ of acetylsalicylic acid, administered orally once a day. Ten days later, the small-molecular-weight heparin was replaced with oral ticlopidine, dosed at 250 $\mathrm{mg}$ twice a day, or with $75 \mathrm{mg}$ of clopidogrel, administered orally once a day. The implanted stent-grafts were evaluated with Doppler ultrasound at three, six, and 12 months post-op, followed by an annual follow-up examination, and with CTA at three, six, and 12 months post-

Table 2. Intervals between primary and secondary procedures. Patients characteristics at the time of secondary procedure

\begin{tabular}{|c|c|c|c|c|c|}
\hline $\begin{array}{l}\text { Pt } \\
\text { no. }\end{array}$ & $\begin{array}{l}\text { Interval be- } \\
\text { tween pri- } \\
\text { mary and } \\
\text { secondary } \\
\text { procedures } \\
\text { (years) }\end{array}$ & Indication for secondary procedure & Symptoms & Co-morbidities & $\begin{array}{l}\text { ASA } \\
\text { class }\end{array}$ \\
\hline 1 & 2 & $\begin{array}{l}\text { Pseudoaneurysms of proximal and } \\
\text { distal anastomosis }\end{array}$ & $\begin{array}{l}\text { Abdominal and lum- } \\
\text { bar pain }\end{array}$ & $\begin{array}{l}\text { Hypertension, CAD, spondylo- } \\
\text { sis, left nephrosclerosis }\end{array}$ & IV \\
\hline 2 & 3 & $\begin{array}{l}\text { Pseudoaneurysm of proximal anasto- } \\
\text { mosis }\end{array}$ & $\begin{array}{l}\text { Abdominal and lum- } \\
\text { bar pain, hematuria }\end{array}$ & $\begin{array}{l}\text { Hypertension, CAD, MI, nico- } \\
\text { tinism }\end{array}$ & IV \\
\hline 3 & 4 & $\begin{array}{l}\text { Pseudoaneurysms of proximal anasto- } \\
\text { mosis, true aneurysm of the right CIA }\end{array}$ & asymptomatic & $\begin{array}{l}\text { Hypertension, COPD, diabetes, } \\
\text { obesity }(\mathrm{BMI}>35) \text {, hiperchole- } \\
\text { sterolemia }\end{array}$ & III \\
\hline 4 & 3 & $\begin{array}{l}\text { Pseudoaneurysm of proximal anasto- } \\
\text { mosis, gastroduodenal fistula }\end{array}$ & $\begin{array}{l}\text { Abdominal pain, he- } \\
\text { matemesis, gastroin- } \\
\text { testinal bleeding }\end{array}$ & $\begin{array}{l}\text { Hypertension, CAD, MI, occlu- } \\
\text { sion of the right CIA and EIA }\end{array}$ & IV \\
\hline 5 & 8 & $\begin{array}{l}\text { True aneurysm above proximal ana- } \\
\text { stomosis }\end{array}$ & $\begin{array}{l}\text { Pulsating abdominal } \\
\text { mass }\end{array}$ & $\begin{array}{l}\text { Chronic renal failure, chronic } \\
\text { pancteatitis, nicotinism, BMI } \\
\text { I5,6 }\end{array}$ & III \\
\hline 6 & 4 & Bilateral true aneurysms of $\mathrm{CIA}$ & asymptomatic & $\begin{array}{l}\text { Bilateral aneurysms of IIA, } \\
\text { hypertension, CAD, CABG }\end{array}$ & III \\
\hline 7 & 4 & $\begin{array}{l}\text { Pseudoaneurysm of proximal anasto- } \\
\text { mosis, bilateral true aneurysms of } \mathrm{CIA}\end{array}$ & asymptomatic & Hypertension, CAD, nicotinism & III \\
\hline 8 & 10 & $\begin{array}{l}\text { Pseudoaneurysm of proximal anasto- } \\
\text { mosis, true aneurysms of the right CIA }\end{array}$ & $\begin{array}{l}\text { Abdominal pain, pul- } \\
\text { sating abdominal mass }\end{array}$ & $\begin{array}{l}\text { Diabetes, prostatectomy (can- } \\
\text { cer), radiotherapy }\end{array}$ & II \\
\hline 9 & 10 & $\begin{array}{l}\text { Pseudoaneurysm of proximal anasto- } \\
\text { mosis, true aneurysms of the right } \mathrm{CIA}\end{array}$ & asymptomatic & $\begin{array}{l}\text { CAD, MI, PTCA, obesity, } \\
\text { COPD }\end{array}$ & III \\
\hline 10 & 6 & $\begin{array}{l}\text { Pseudoaneurysm of proximal anasto- } \\
\text { mosis, bilateral true aneurysms of } \mathrm{CIA}\end{array}$ & asymptomatic & Hypertension, diabetes, stroke & III \\
\hline II & 9 & Bilateral true aneurysms of CIA & asymptomatic & $\begin{array}{l}\text { Trombocytopenia, COPD, } \\
\text { hypertension }\end{array}$ & III \\
\hline 12 & 4 & $\begin{array}{l}\text { Pseudoaneurysm of proximal anasto- } \\
\text { mosis }\end{array}$ & asymptomatic & $\begin{array}{l}\text { Hypertension, diabetes, stroke, } \\
\text { AF }\end{array}$ & III \\
\hline 13 & 11 & $\begin{array}{l}\text { Pseudoaneurysm of proximal anasto- } \\
\text { mosis }\end{array}$ & $\begin{array}{l}\text { Abdominal and lum- } \\
\text { bar pain }\end{array}$ & $\begin{array}{l}\text { Sigmoidectomy (cancer), } \\
\text { hypertension }\end{array}$ & II \\
\hline
\end{tabular}


Table 2. cont. Intervals between primary and secondary procedures. Patients characteristics at the time of secondary procedure

\begin{tabular}{|c|c|c|c|c|c|}
\hline $\begin{array}{l}\text { Pt } \\
\text { no. }\end{array}$ & $\begin{array}{l}\text { Interval be- } \\
\text { tween pri- } \\
\text { mary and } \\
\text { secondary } \\
\text { procedures } \\
\text { (years) }\end{array}$ & Indication for secondary procedure & Symptoms & Co-morbidities & $\begin{array}{l}\text { ASA } \\
\text { class }\end{array}$ \\
\hline 14 & 9 & $\begin{array}{l}\text { Pseudoaneurysm of proximal anasto- } \\
\text { mosis, gastroduodenal fistula }\end{array}$ & $\begin{array}{l}\text { Gastrointestinal } \\
\text { bleeding }\end{array}$ & $\begin{array}{l}\text { Hypertension, CAD, gastritis, } \\
\text { right lobectomy (cancer), } \\
\text { nicotinism }\end{array}$ & IV \\
\hline 15 & 8 & Pseudoaneurysm of distal anastomosis & Lumbar pain & $\begin{array}{l}\text { Hypertension, CAD, } 2 \times \mathrm{MI} \text {, } \\
\text { nicotinism }\end{array}$ & III \\
\hline 16 & 7 & $\begin{array}{l}\text { Ruptured pseudoaneurysm of proximal } \\
\text { anastomosis, retrioperitoneal haema- } \\
\text { toma }\end{array}$ & Lumbar pain & Hypertension, nicotinism & IV \\
\hline 17 & II & $\begin{array}{l}\text { Ruptured pseudoaneurysm of proximal } \\
\text { anastomosis }\end{array}$ & $\begin{array}{l}\text { Abdominal pain, hy- } \\
\text { povolemic shock }\end{array}$ & $\begin{array}{l}\text { Hypertension, diabetes, } \\
\text { Parkinson disease, occlusion of } \\
\text { the left CIA and EIA }\end{array}$ & IV \\
\hline 18 & 12 & Bilateral true aneurysms of $\mathrm{CIA}$ & asymptomatic & $\begin{array}{l}\text { Hypertension, CAD, MI, } \\
\text { spondylosis }\end{array}$ & III \\
\hline 19 & 10 & $\begin{array}{l}\text { Pseudoaneurysm of proximal anasto- } \\
\text { mosis }\end{array}$ & asymptomatic & $\begin{array}{l}\text { Hypertension, diabetes, CAD, } \\
\text { chronic renal failure }\end{array}$ & III \\
\hline 20 & 10 & $\begin{array}{l}\text { Pseudoaneurysm of proximal anasto- } \\
\text { mosis }\end{array}$ & asymptomatic & Hypertension, $2 \times$ stroke & III \\
\hline 21 & 14 & Pseudoaneurysm of distal anastomosis & $\begin{array}{l}\text { Pulsating abdominal } \\
\text { mass }\end{array}$ & $\begin{array}{l}\text { Hypertension, CAD, CABG, } \\
\text { bilateral occlusion og SFA }\end{array}$ & III \\
\hline 22 & 10 & $\begin{array}{l}\text { TAAA, pseudoaneurysm of proximal } \\
\text { anastomosis }\end{array}$ & asymptomatic & $\begin{array}{l}\text { Gastritis, } 2 x \text { laparotomy for ga- } \\
\text { stric perforation, hypertension, } \\
\text { aortoduodenal fistula }\end{array}$ & III \\
\hline 23 & 6 & $\begin{array}{l}\text { Pseudoaneurysm of proximal anasto- } \\
\text { mosis }\end{array}$ & asymptomatic & $\begin{array}{l}\text { Hypertension, CAD, MI, } \\
\text { nicotinism }\end{array}$ & III \\
\hline 24 & 7 & Pseudoaneurysm of distal anastomosis & asymptomatic & Hypertension, stroke & III \\
\hline 25 & 8 & $\begin{array}{l}\text { Pseudoaneurysm of proximal anasto- } \\
\text { mosis, gastroduodenal fistula }\end{array}$ & $\begin{array}{l}\text { Abdominal pain, he- } \\
\text { matemesis, gastroin- } \\
\text { testinal bleeding }\end{array}$ & $\begin{array}{l}\text { Gastritis, laparotomy for gastric } \\
\text { perforation, hypertension }\end{array}$ & III \\
\hline 26 & 6 & $\begin{array}{l}\text { Para-anstomotic (proximal) and supra- } \\
\text { renal aneurysm }\end{array}$ & asymptomatic & Hypertension, CAD, CABG & \\
\hline
\end{tabular}

TAAA: thoracoabdominal aortic aneurysm, CAD: coronary artery disease, MI: myocardial infarction, COPD: chronic obstructive disease, IIA: internal iliac artery, AF: atrial fibrillation

op, and later once a year or in the event of abnormalities revealed in ultrasound. When analysing the study group, the following factors were taken into consideration: indications for the primary procedure, type of the implanted vascular graft, time from the primary procedure and the endovascular reintervention, type of the stent-graft used, type of the anaesthesia chosen during the endovascular surgery, additional procedures performed as part of the reoperation, and early and long-term results.

\section{Results}

The diameters of proximal new aneurysms or pseudoaneurysm ranged between 45 and $69 \mathrm{~mm}$. New iliac aneurysm diameters ranged between 47 and 64 $\mathrm{mm}$, and distal para-anastomotic pseudoaneurysms diameter ranged between 34 and $49 \mathrm{~mm}$. In six cases bifurcated prosthesis was implanted with the creation of neobifurcation. The length between the lower renal artery and graft bifurcation ranged from 54 to $68 \mathrm{~mm}$.

Twenty one bifurcated stent-grafts were implanted as a secondary intervention, including eleven Zenith grafts (Cook, Bloomington, IN), six Excluder grafts (Gore, Flagstaff, AZ), two Talent grafts (Medtronic Vascular, Santa Rosa, CA), one AFX graft (Endologix Inc, Irvine, Calif), one Aorfix graft (Lombard Medical, Didcot, UK), and two branched devices - Zenith Branch stent-graft (Cook Medical, Brisbane, AUS) and Colt (Jotec GmbH, Hechingen, Germany). 
Table 3. Details of secondary intervention

\begin{tabular}{|c|c|c|c|c|c|c|c|}
\hline Pt no. & $\begin{array}{l}\text { Type of endograft } \\
\text { used }\end{array}$ & Additional procedures & Anesthesia & $\begin{array}{l}\text { Time of the } \\
\text { secondary } \\
\text { procedure } \\
\text { (mins) }\end{array}$ & $\begin{array}{l}\text { Time of } \\
\text { fluoro- } \\
\text { scopy } \\
\text { (mins) }\end{array}$ & $\begin{array}{l}\text { Contrast } \\
\text { volume } \\
(\mathrm{mL})\end{array}$ & $\begin{array}{l}\text { Estimated } \\
\text { blood loss } \\
(\mathrm{mL})\end{array}$ \\
\hline I & Bifurcated Zenith & Proximal cuff & General & 156 & 32 & 280 & 220 \\
\hline 2 & $\begin{array}{l}\text { Tube Zenith Custom } \\
\text { Made (see: Fig. I) }\end{array}$ & None & Spinal & 103 & 20 & 120 & 110 \\
\hline 3 & Bifurcated Excluder & Coiling of both IIA & Spinal & 226 & 40 & 340 & 300 \\
\hline 4 & $\begin{array}{l}\text { Module of thoracic } \\
\text { Zenith (see: Fig. 2) }\end{array}$ & None & Spinal & 82 & 14 & 120 & 100 \\
\hline 5 & Bifurcated Zenith & None & Spinal & 201 & 42 & 200 & 100 \\
\hline 6 & Bifurcated Excluder & Coiling of both IIA & Spinal & 183 & 40 & 300 & 230 \\
\hline 7 & Bifurcated Excluder & $\begin{array}{l}\text { PTA of the left EIA, im- } \\
\text { plantation of Hemobahn } \\
\text { stent-graft }\end{array}$ & Spinal & 193 & 45 & 300 & 250 \\
\hline 8 & Bifurcated Excluder & None & Spinal & 125 & 21 & 200 & 150 \\
\hline 9 & Bifurcated Zenith & None & Spinal & 145 & 26 & 180 & 200 \\
\hline 10 & Bifurcated Zenith & None & Spinal & 189 & 32 & 230 & 300 \\
\hline 11 & Bifurcated Excluder & None & Spinal & 163 & 27 & 270 & 180 \\
\hline 12 & Bifurcated Zenith & None & Spinal & 132 & 22 & 200 & 150 \\
\hline 13 & Bifurcated Talent & None & Spinal & 135 & 18 & 180 & 200 \\
\hline 14 & Bifurcated Zenith & None & Spinal & 261 & 36 & 150 & 200 \\
\hline 15 & Bifurcated Aorfix & $\begin{array}{l}\text { Contralateral stent-graft } \\
\text { leg cannulated from } \\
\text { axillary approach }\end{array}$ & Spinal & 185 & 40 & 300 & 150 \\
\hline 16 & Bifurcated Zenith & None & Spinal & 174 & 38 & 350 & 250 \\
\hline 17 & Wallgraft & $\begin{array}{l}\text { Evacuation of retroperito- } \\
\text { neal haematoma }\end{array}$ & General & $71+122$ & 7 & 120 & $\begin{array}{l}150+ \\
1200\end{array}$ \\
\hline 18 & Bifurcated Talent & None & $\begin{array}{l}\text { Local, } \\
\text { analgosedation }\end{array}$ & 105 & 23 & 200 & 100 \\
\hline 19 & Bifurcated Zenith & None & Spinal & 210 & 40 & 260 & 120 \\
\hline 20 & $\begin{array}{l}\text { Bifurcated Zenith } \\
\text { (see: Fig. 3) }\end{array}$ & None & Spinal & 220 & 35 & 350 & 300 \\
\hline 21 & Bifurcated Excluder & $\begin{array}{l}\text { Straight Gelsoft prosthesis } \\
\text { sutured onto the right leg } \\
\text { of the stent-graft, distal } \\
\text { anastomosis with CFA }\end{array}$ & Spinal & $115+95$ & 40 & 180 & $\begin{array}{l}130+ \\
350\end{array}$ \\
\hline 22 & $\begin{array}{l}\text { Bifurcated branched } \\
\text { Zenith }\end{array}$ & None & Spinal & 530 & 180 & 420 & 650 \\
\hline 23 & Bifurcated Zenith & None & Spinal & 145 & 30 & 150 & 150 \\
\hline 24 & Bifurcated Zenith & None & Spinal & 160 & 25 & 150 & 200 \\
\hline 25 & Two tube Endurant & None & Spinal & 199 & 30 & 180 & 150 \\
\hline 26 & $\begin{array}{l}\text { Branched Colt } \\
\text { (see: Fig. 4) }\end{array}$ & $\begin{array}{l}\text { Implantation of thoracic } \\
\text { stent-graft }\end{array}$ & Genaral & 548 & 210 & 463 & 600 \\
\hline
\end{tabular}

Five tube stent-grafts were also implanted, including the Zenith thoracic stent-graft module (Cook, Bloomington, IN), Wallgraft (Boston Scientific/Meditech, Newton, MA), "custom-made" Zenith (Cook, Bloomington, IN), and two Endurant (Medtronic, Santa Rosa, Calif) stent-grafts. One patient required the implantation of two aorto-uniiliac stent-grafts, followed by a bifurcated stent-graft a year later. Twenty-two of the endovascular procedures were performed under epidural anaesthesia. In three cases, general anaesthesia was chosen, and in a single patient, local anaesthesia was combined with intravenous sedation. All stent grafts have been implanted from open femoral access 
with additional surgical exposure of axillary artery in two cases of branched devices. Eight patients required additional intraoperative procedures. In one case, due to the kinking of the external iliac artery at the end of the stent-graft limb, an additional Wallgraft stent-graft was implanted. In another patient, two-stage embolization of both internal iliac arteries was required in order to prevent type II endoleak. In a yet another case, during the modelling of the stent-graft limb, the balloon catheter was inadvertently positioned beyond its distal end. The dilated balloon catheter damaged the external iliac artery, which required the implantation of a peripheral stent-graft. Difficulties with the cannulation of the contralateral stent-graft limb required the use of an additional axillary access in two patients, and in one patient a cross-over technique was used. In the case treated for the rupture of a pseudoaneurysm at the proximal anastomosis of an iliofemoral graft, surgical evacuation of a retroperitoneal hematoma was necessary. In one patient, it was impossible to expand the contralateral limb of the stent-graft, left in the common iliac artery due to the displacement of the main body. The open conversion was performed. Once the non-expanded limb was released, it was positioned in the right common iliac artery, and a $10 \mathrm{~mm}$ vascular prosthesis was sewn onto it. Eventually, in all of the analysed cases, perianastomotic pseudoaneurysms and true aneurysms were successfully managed. Two cases of type I endoleaks were reported and were managed intraoperatively. Detailed information about procedures is presented in Table 3. No deaths occurred in the perioperative period. In six patients, there were early local complications, including two cases of bleeding from the suture line on femoral artery, two cases of lymphatic leakage, wound infection, and finger paresis of the left hand. In eight patients, early general complications were reported, one of which was considered as severe. In three cases postimplantation syndrome developed. In two patients postoperative renal insufficiency was reported. Two patients complained of buttock claudication. One patient was diagnosed with myocardial infarction. The average length of hospital stay was seven days. Patients have been followed up for 6 to 90 months. No endoleaks nor stent-graft migrations have been reported. The diameter of the aneurysms remained stable in I I cases, the shrinkage of the sac was noticed in 13 cases, and in two cases we observed slight sac growth from 2 to $4 \mathrm{~mm}$ without any detectable reason. The patient with aorto-duodenal fistula, in whom two straight Endurant and one AFX stent-grafts were implanted, required a reintervention 12 months later. Due to recurrent episodes of gastrointestinal bleeding, the patient had an additional bifurcated AFX stent-graft implanted. No evident radiological signs of aorto-enteric fistula were revealed. In long-term follow-up, seven deaths were reported of causes unrelated to the applied treatment method (lymphoma, myocardial infarction, two cases of an ischemic brain stroke, pancreatic cancer, and disseminated neoplastic disease). One patient, treated for aorto-enteric fistula, died of cachexia and systemic infection 6 months after the endovascular procedure. Sixteen patients remain in follow-up. Two patients lost from follow-up (Table 4).
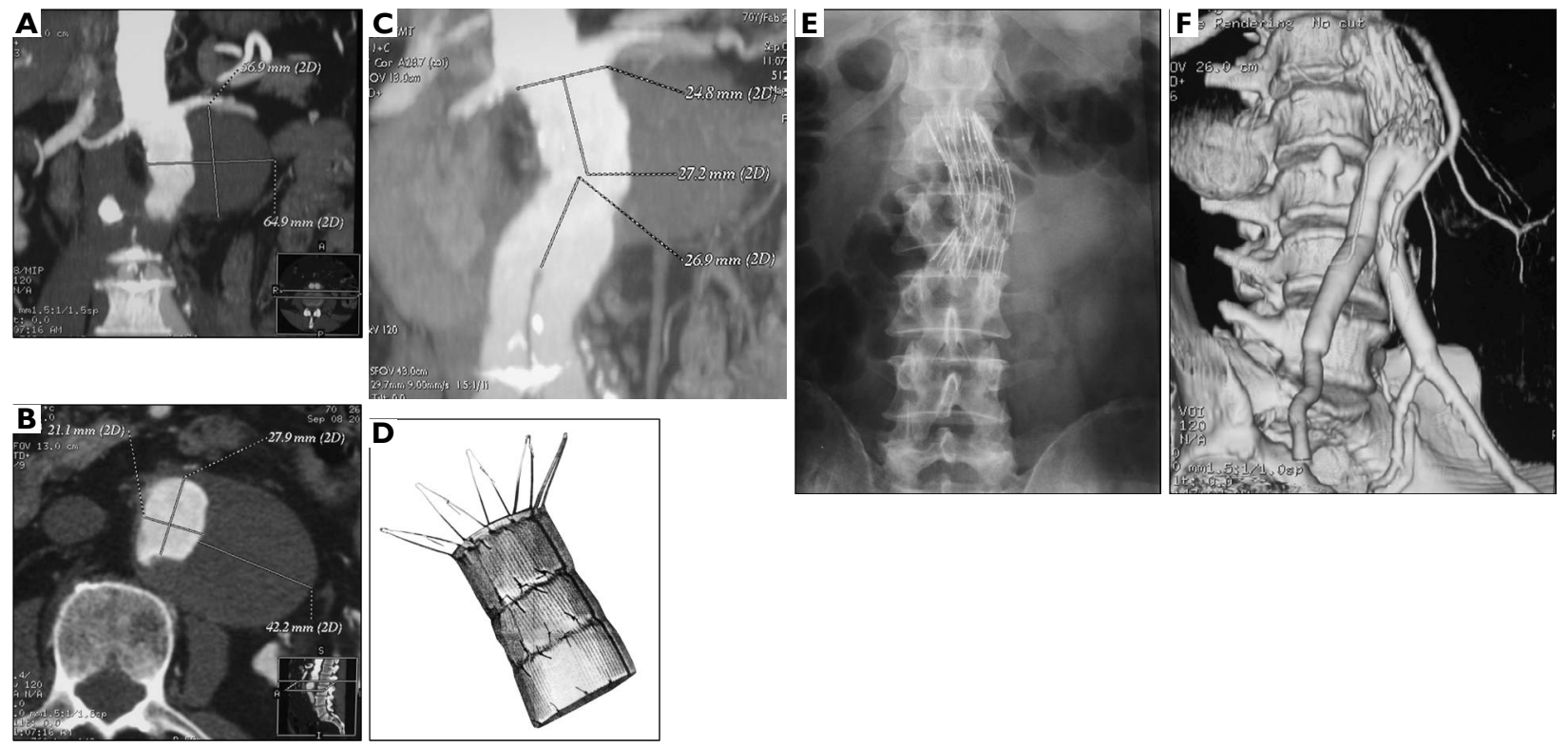

Figure I. Patient 2. CT scans presenting a huge haematoma at the level of proximal anastomosis causing dislocation of the left renal artery $(\mathbf{A}, \mathbf{B})$ and $54 \mathrm{~mm}$ the distance between the orifices of renal arteries and bifurcation of aorto-bifemoral prosthesis $(\mathbf{C})$. A custom-made tube Zenith with reduction of the diameter of each segment 28/30/32 and $56 \mathrm{~mm}$ in length (D). Plain abdominal X-ray showing the unique structure of the conical tube stent-graft $(\mathbf{E})$. A volume rendering CT reconstruction one year after implantation shows the segmented structure of stent-graft and narrow legs of the previously implanted bifurcated prosthesis (F) 

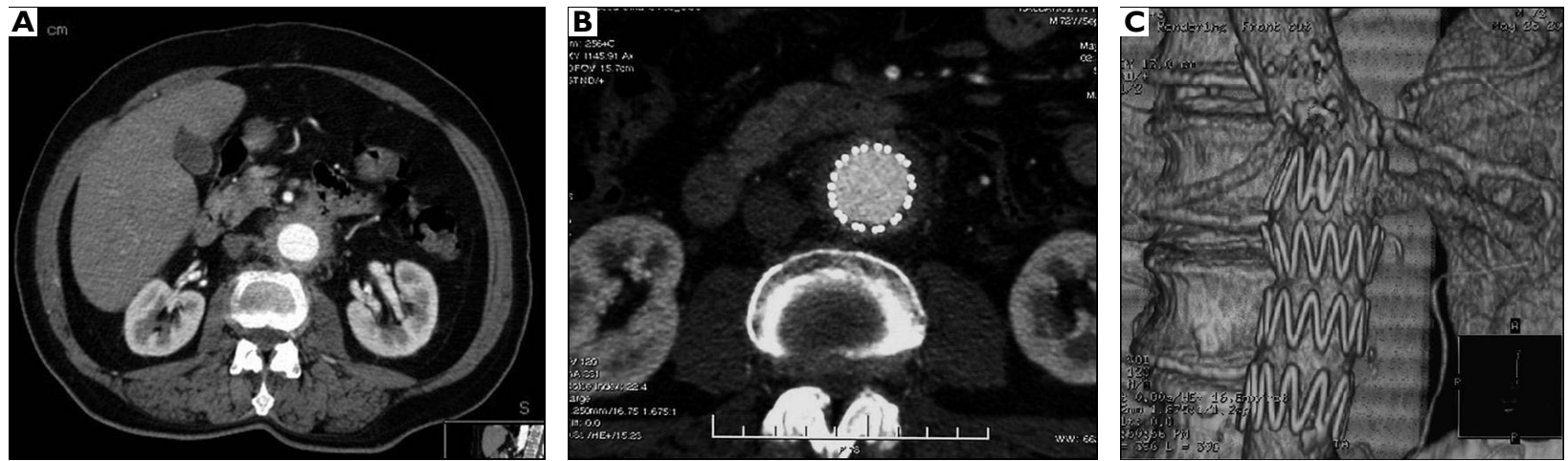

Figure 2. Patient 4. Contrast-enhanced CT scan shows inflammatory infiltration around proximal anastomosis with previously implanted aortic graft, retracting intestinal loop (A). Postoperative CT scan performed 6 months after stent-graft implantation demonstrates the regression of the inflammatory infiltration (B). A volume rendering CT reconstruction shows a fully and properly deployed structure of stent-graft $(\mathbf{C})$
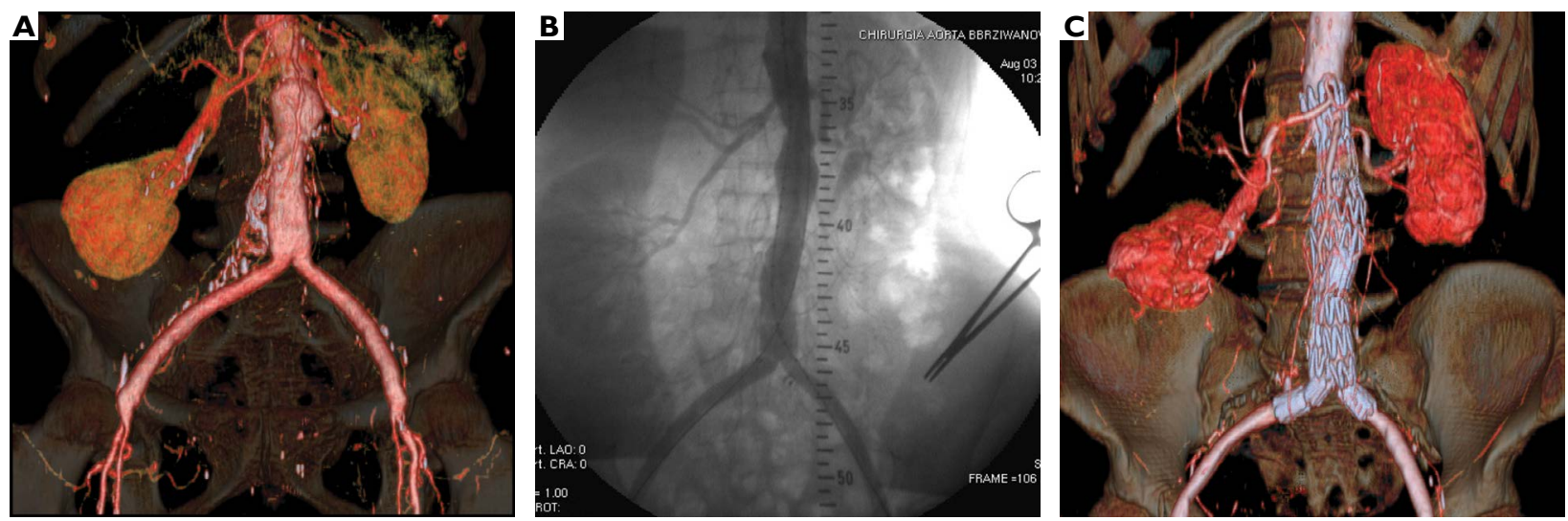

Figure 3. Patient 20. A volume rendering CT reconstruction shows pseudoaneurysm of proximal anastomosis $(\mathbf{A})$. Intraoperative control angiogram after implantation of bifurcated Zenith stent-graft $(\mathbf{B})$. A volume rendering $\mathrm{CT}$ reconstruction performed 12 months after the secondary procedure (C)
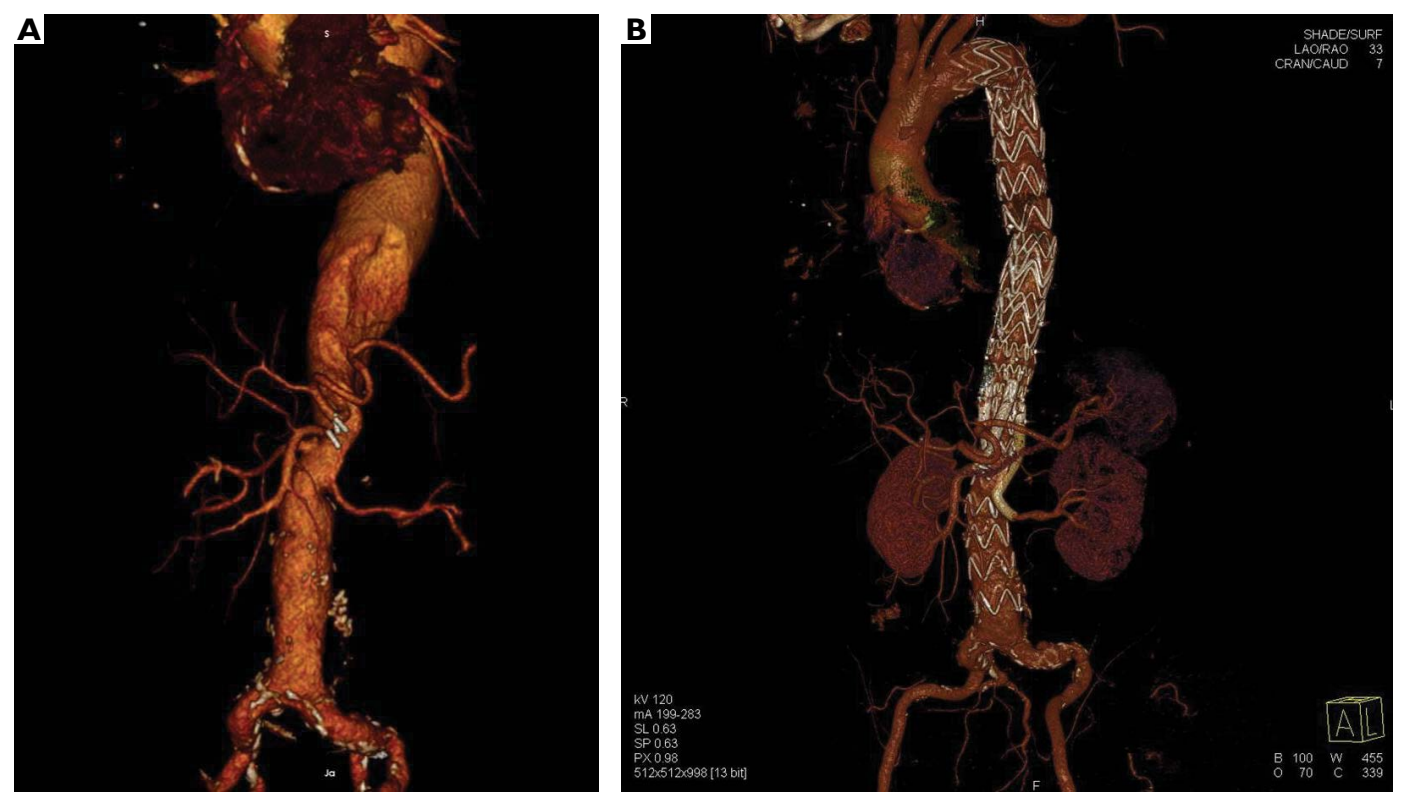

Figure 4. Patient 26. A volume rendering CT reconstruction shows proximal paraanatomotic and suprarenal aneurysm (A). A volume rendering CT performed 12 months after implantation of branched Colt stent-graft (B) 
Table 4. Short and long term follow up after secondary procedure including the changes of aneurysm sac diameters (comparing to diameter before the secondary intervention)

\begin{tabular}{|c|c|c|c|c|c|c|}
\hline $\begin{array}{l}\text { Pt } \\
\text { no. }\end{array}$ & $\begin{array}{l}\text { Lenght } \\
\text { of ho- } \\
\text { spital } \\
\text { stay } \\
\text { (days) }\end{array}$ & $\begin{array}{l}\text { Early complications (up } \\
\text { to } 30 \text { days) }\end{array}$ & $\begin{array}{l}\text { Follow up } \\
\text { (months) }\end{array}$ & Late complications & $\begin{array}{l}\text { Current status In } \\
\text { follow-up }\end{array}$ & $\begin{array}{l}\text { Chan- } \\
\text { ges in } \\
\text { aneury- } \\
\text { sm dia- } \\
\text { meter }\end{array}$ \\
\hline 1 & 10 & $\begin{array}{l}\text { Transient renal } \\
\text { impairment }\end{array}$ & 30 & None & Death (lymphoma) & - \\
\hline 2 & 6 & None & 90 & None & Under observation & \\
\hline 3 & 8 & $\begin{array}{l}\text { Lymph likeage from the } \\
\text { groin }\end{array}$ & 86 & None & Under observation & \\
\hline 4 & 14 & None & 24 & None & Death (MI) & - \\
\hline 5 & 5 & None & 83 & None & Under observation & \\
\hline 6 & 5 & Buttock claudication & 80 & None & Under observation & \\
\hline 7 & 5 & $\begin{array}{l}\text { Bleeding from suture } \\
\text { line on femoral artery }\end{array}$ & 72 & None & Under observation & \\
\hline 8 & 5 & $\begin{array}{l}\text { Postimplantation } \\
\text { syndrome }\end{array}$ & 74 & None & Under observation & \\
\hline 9 & 6 & $\begin{array}{l}\text { Lymph likeage from the } \\
\text { groin }\end{array}$ & 68 & None & Under observation & \\
\hline 10 & 6 & $\begin{array}{l}\text { Bleeding from suture } \\
\text { line on femoral artery }\end{array}$ & 66 & $\begin{array}{l}\text { Acute left lower limb ischaemia - } \\
\text { thrombisis of the popliteal artery } \\
\text { aneurysm three years after secon- } \\
\text { dary procedure, femoro-popliteal } \\
\text { venous by-pass }\end{array}$ & Under observation & \\
\hline 11 & 5 & Buttock claudication & 65 & TAAA & Under observation & \\
\hline 12 & 7 & $\begin{array}{l}\text { Postimplantation syn- } \\
\text { drome, acute ischemia } \\
\text { of the right lower limb } \\
\text { (embolus in popliteal } \\
\text { artery) }\end{array}$ & 48 & None & Death (stroke) & - \\
\hline 13 & 5 & None & 40 & None & Death (cancer) & - \\
\hline 14 & 5 & None & 6 & General infection & Death (cachexia) & - \\
\hline 15 & 6 & $\begin{array}{l}\text { Hematoma In the left } \\
\text { axillary fossa, paresthe- } \\
\text { sia (left hand) }\end{array}$ & 72 & None & $\begin{array}{l}\text { Rehabilitation, } \\
\text { under observation }\end{array}$ & \\
\hline 16 & 6 & None & 34 & None & Lost from follow-up & - \\
\hline 17 & 9 & None & 64 & Postoperative hernia & Under observation & \\
\hline 18 & 5 & $\begin{array}{l}\text { Postimplantation syn- } \\
\text { drome }\end{array}$ & 18 & None & $\begin{array}{l}\text { Death (pancreatic } \\
\text { cancer) }\end{array}$ & - \\
\hline 19 & 6 & $\begin{array}{l}\text { Transient renal impair- } \\
\text { ment }\end{array}$ & 56 & None & Under observation & \\
\hline 20 & 6 & None & 52 & None & Lost from follow-up & - \\
\hline 21 & 10 & MI & 46 & Postoperative hernia & Under observation & \\
\hline 22 & 6 & None & 40 & None & Under observation & \\
\hline 23 & 5 & None & 40 & None & Under observation & \\
\hline 24 & 5 & None & 46 & None & Under observation & \\
\hline 25 & 8 & None & 20 & $\begin{array}{l}\text { Gastrointestinal beeding, implanta- } \\
\text { tion of bifurcated AFX stent-graft }\end{array}$ & Death (stroke) & - \\
\hline 26 & 6 & $\begin{array}{l}\text { Type II endoleak, re- } \\
\text { solved }\end{array}$ & 36 & None & Under observation & \\
\hline
\end{tabular}




\section{Discussion}

The prevailing view in the literature is that patients with anastomotic and new true aneurysms should be qualified for surgery based on the same principles as in the case of primary aneurysms [3]. On the other hand, due to the high risk of rupture, each pseudoaneurysm also constitutes an urgent indication for surgical treatment [4]. A patient qualified for endovascular repair requires an individual approach to proper pre-operative planning and selection of the stent-graft to be implanted. Based on our findings, we conclude that changed anatomy of the aorta and the presence of previously implanted vascular prosthesis might be a source of numerous technical difficulties. Familiarity with those abnormal conditions is crucial both at the stage of qualifying patients for endovascular treatment as well as at the stage of performing the secondary procedure. The distance between the proximal anastomosis of a vascular graft and the origin of the lowest renal artery determines the possibility of using the endovascular method. The problem of the short neck affects primarily the patients operated on for abdominal aortic aneurysms, as in the course of the primary surgery, the prosthesis is sewn just below the renal arteries. Initially, in order to manage an anastomotic aneurysm safely, the distance could not be shorter than $15 \mathrm{~mm}$. Presently, the available suprarenal systems make it possible to extend the indications for such endovascular interventions. Ten Bosch et al. successfully excluded anastomotic aneurysms with a short $10 \mathrm{~mm}$ neck, while Faries et al. did the same for a $5 \mathrm{~mm}$ neck. Reyes et al. described the use of fenestrated, branched or chimney grafts in case of pararenal aneurysms [5-7]. In our opinion, the safe length of the neck should not be shorter than $15 \mathrm{~mm}$ to provide the proper sealing zone. In shorter neck we consider the use of chEVAR or chEVAS to reduce the risk of Type I endoleak. The technical difficulties during the implantation may also stem from the too short a distance between the origin of the renal arteries and the stent-graft bifurcation. To qualify a patient for endovascular management, the distance cannot be shorter than the length of the main body of the stent-graft. The situation is most frequently encountered in patients managed for the Leriche syndrome, in whom a short main body is sutured to the aorta during the open repair. An additional difficulty may be caused by the difference in the diameters of the aorta and of the prosthesis. The disproportion often renders standard stent-graft implantation impossible. The problem may be solved by using specially designed and custom-made stent-grafts. In a similar situation, we used a unique stent-graft with suprarenal fixation, whose special feature was the gradually increasing diameter of the consecutive segments, by $2 \mathrm{~mm}$ each, bringing the diameter from 28 to $32 \mathrm{~mm}$. What made the procedure even more difficult was the short distance between the renal arteries and the graft bifurcation. Successful management of the pseudoaneurysm required the use of three segments with total length amounted to $56 \mathrm{~mm}$ (Fig. I). Yet another way of solving the above-mentioned problem was described by York et al. They used a technique consisting of implantation of consecutive overlapping sealing cuffs [8]. A modification of the method was presented by Zhou et al., who used two or three such sealing cuffs, creating a new type of a telescopic endovascular stent-graft, whose length and diameter could be freely regulated [6]. Other difficulties associated with endovascular reinterventions are linked to the diameter of the implanted graft, which may increase with time. To guarantee the appropriate expansion of the stent-graft, it should not exceed $32-33 \mathrm{~mm}$ at the level of the proximal anastomosis. Bifurcated graft limbs that are narrower than $8 \mathrm{~mm}$ may lead to difficulties with the introduction of the system in some cases. The problem may be resolved with the use of the low profile systems $[9,10]$. Stenosis at surgical anastomosis may preclude the appropriate expansion of the stent-graft, and the end-toside anastomosis is conducive to its deformation [II]. Such grafts are particularly useful in short-neck aneurysms, making it possible to avoid hybrid procedures and extra-anatomic bypass grafting [12]. The chimney EVAR and EVAS have also been successfully applied [13, 14]. In technically difficult cases, the secondary intervention may be limited to the implantation of a uniliac stent-graft and an extra-anatomic femoro-femoral bypass [15]. Cases of successful embolization of small proximal anastomotic pseudoaneurysms have also been described, involving the use of detachable coils or acrylic glue [16]. Even though endovascular treatment is less invasive, it is associated with the possibility of complications just like any other type of surgical management. Complications may occur intraoperatively, in the early post-operative period or several years following the procedure. In the present study, we reported a high rate of successful procedures with primary technical success accomplished in $96 \%$ of the cases. We detected few intra- and post-operative complications, with most of them being associated with the femoral open access. Sometimes, in order to complete the implantation, it was necessary to perform additional intraoperative procedures. According to the literature findings, the most common and the most serious complications associated with the endovascular method include type I endoleaks. When left without intervention, the endoleaks may result in stent-graft migration and secondary rupture of an aneurysm [17]. Sachdev et al. reported two cases of type I endoleaks in a group of 38 reop- 
erated subjects [18]. In Tsang's [19] study, they have been found postoperatively in $27 \%$ of patients. Tshomba et al. [I] described five cases of late-type I endoleaks, and four migration cases, with the reintervention rate totalling $17 \%$. The short and angulated neck, typical of aneurysms at proximal anastomoses, is conducive to such complications. According to some authors, type I endoleaks occur more often in that group of patients as most of the procedures are urgent, and a short planning period has a negative impact on long-term results $[6$, 18]. A topic that is broadly discussed in the literature is that of the increased risk of migration of stents anchored within aortic grafts. According to some experts, aortic prostheses are highly susceptible to stretching, and even oversizing the stent-graft by $20-30 \%$ does not prevent its migration. Hence, it is recommended that stent-grafts be anchored within the healthy segments of the aorta [20]. The analysis of the collected data makes it impossible to unequivocally conclude whether anchoring the proximal end of the main limb in the prosthesis is completely safe. In most of the analysed cases, patient anatomy enabled implanting the endovascular stent-graft just below the renal arteries in such a way so as to anchor the proximal end of the stent-graft in an unchanged aortic wall (Fig. 2). In one case, due to the disproportion between the native abdominal aortic diameter and the diameter of the graft, the main body of the stent-graft was expanded in the lumen of the aortic prosthesis. In order to prevent graft migration, its limbs were expanded exactly at the level of the aortic bifurcation (Fig. 3). There were no postoperative complications. In another patient, reoperated for distal anastomotic aneurysm, it was decided that the stent-graft would be sewn in the lumen of a previously implanted vascular graft. Despite of $20 \%$ oversizing, the main limb of the stent-graft was displaced intraoperatively, placing both of the limbs in a single iliac artery. After many attempts cannulation of the limb was unsuccessful, and finally the procedure was completed with open surgery. In a similar situation, Ten Bosch et al. [5] left the stent-graft in place, treating it as a uniiliac one. Having extended the ipsilateral limb, they performed the femoro-femoral bypass. Subsequently, wishing to avoid endoleaks, they ligated the common and internal iliac arteries on the contralateral side from retroperitoneal access. Having analysed the case, we believe that ligating the common iliac artery was reasoned, while leaving a patent internal iliac artery would have made retrograde blood flow to the pelvis possible, with the other artery being covered with stent-graft. Taking into consideration the possibility of postoperative intestinal necrosis associated with endovascular treatment, one should attempt to preserve blood flow through at least one of the internal iliac arteries. If not possible, it is recommended to transpose them or to perform a two-stage embolization of internal iliac arteries several weeks before the surgery, allowing the collateral circulation to develop [2I, 22]. In our group, a two-stage embolization of internal iliac arteries was performed in one case. Another technique which enables the preservation of internal iliac artery patency is the "sandwich" method, consisting of inserting additional stent-grafts in internal iliac arteries from the axillary access [23, 24]. Our observations suggest that an appropriate patient selection and proper performance of the surgery makes it possible to minimize the risk of complications. In the analysed group of 26 cases, we reported two type I endoleaks treated immediately, two type II endoleaks left for further observation and a single case of stent-graft migration. In one patient, the stent-graft was additionally expanded with a balloon catheter at the level of the proximal anastomosis. In another case, it was necessary to implant an additional sealing cuff. The patient affected by stent-graft migration required conversion to open repair. In short-term and long-term follow-up, there have been no other cases of endoleaks, stent-graft migration or thrombosis. The patient suffering from aorto-enteric fistula required an additional implantation of a bifurcation stent-graft due to the recurrent episodes of gastrointestinal bleeding. Another patient with a fistula failed to give his consent for stent-graft explantation, and died of systemic infection six months post-op. When analysing the population of patients with aorto-enteric fistulas, I agree with the prevailing opinion that haemorrhage is the only ground for managing a fistula with a stent-graft, as it is a direct life-saving procedure in that case. Due to it being a potential source of infection, once the patient's general condition is stable, it is recommended to remove the stent-graft and proceed with vascular reconstruction. Taking all of the above into consideration, one can conclude that endovascular treatment is a bridging therapy in those situations. In cases of elective surgery, conventional surgical treatment should be considered first [25].

\section{Conclusion}

Endovascular perianastomotic aneurysm treatment is technically feasible and associated with a low risk of perioperative complications, and a high surgical efficacy. When planning the reintervention, one should take into account the altered anatomy of the aorto-iliac segment. Familiarity with the equipment and experience in the endovascular techniques is of crucial significance when managing patients with this pathology.

\section{Conflict of interest}

None. 


\section{References:}

I. Tshomba Y, Mascia D, Kahlberg A, et al. On-label use of commercially-available abdominal endografts for para-anastomotic aneurysms and pseudoaneurysms after infrarenal abdominal aortic aneurysm open repair. Eur J Vasc Endovasc Surg. 2013; 46(6): 657-666, doi: 10.1016/j.ejvs.2013.09.013, indexed in Pubmed: 24119469.

2. Gawenda M, Zaehringer M, Brunkwall J. Open versus endovascular repair of para-anastomotic aneurysms in patients who were morphological candidates for endovascular treatment. J Endovasc Ther. 2003; 10(4): 745-75I, doi: 10.1 177//52660280301000410, indexed in Pubmed: 14533968.

3. Abou-Zamzam AM, Ballard JL. Management of sterile para-anastomotic aneurysms of the aorta. Semin Vasc Surg. 200I; 14(4): 282-29I, indexed in Pubmed: I I 740836.

4. Treiman GS, Weaver FA, Cossman DV, et al. Anastomotic false aneurysms of the abdominal aorta and the iliac arteries. J Vasc Surg. 1988; 8(3): 268-273, indexed in Pubmed: 3418830.

5. Ten Bosch JA, Waasdorp EJ, de Vries JPPM, et al. The durability of endovascular repair of para-anastomotic aneurysms after previous open aortic reconstruction. J Vasc Surg. 201 I; 54(6): |57|-1578, doi: 10. 1016/j.jvs.201 I.04.072, indexed in Pubmed: 21944919.

6. Faries PL, Won J, Morrissey NJ, et al. Endovascular treatment of failed prior abdominal aortic aneurysm repair. Ann Vasc Surg. 2003; I7(I): 43-48, doi: 10.1007/s 10016-001-0335-x, indexed in Pubmed: 12545253.

7. Reyes A, Donas KP, Pitoulias G, et al. Complementary Role of Fenestrated/Branched Endografting and the Chimney Technique in the Treatment of Pararenal Aneurysms After Open Abdominal Aortic Repair. J Endovasc Ther. 2016; 23(4): 599-605, doi: 10.1 I77/15266028/6647363, indexed in Pubmed: 27।70I47.

8. York JW, Sternbergh WC, Lepore MR, et al. Endovascular exclusion of saccular AAAs using "stacked” AneuRx aortic cuffs. J Endovasc Ther. 2002; 9(3): 295-298, doi: 10.1 I 77// 52660280200900307, indexed in Pubmed: 12096943.

9. lerardi $A M$, Tsetis D, loannou C, et al. Ultra-low profile polymer-filled stent graft for abdominal aortic aneurysm treatment: a two-year follow-up. Radiol Med. 2015; 120(6): 542-548, doi: |0.1007/s | |547-0 I5-0499-z, indexed in Pubmed: 25630298.

10. Urlings TAJ, de Vries AC, de Mol van Otterloo JCA, et al. Thromboembolic complications after Zenith ${ }^{\circledR}$ Low Profile Endovascular Graft for infrarenal abdominal aneurysms. Cardiovasc Intervent Radiol. 2015; 38(3): 600-605, doi: 10.1007/s00270014-0972-4, indexed in Pubmed: 25I45923.

II. Laganà D, Carrafiello G, Mangini M, et al. Endovascular treatment of anastomotic pseudoaneurysms after aorto-iliac surgical reconstruction. Cardiovasc Intervent Radiol. 2007; 30(6): I 185-II9I, doi: 10.1007/s00270-007-9047-0, indexed in Pubmed: 17508237.

12. Beck AW, Bos WT, Vourliotakis G, et al. Fenestrated and branched endograft repair of juxtarenal aneurysms after previous open aortic reconstruction. J Vasc Surg. 2009; 49(6): 1387-1394, doi: 10. 10 16/j.jvs.2009.02.009, indexed in Pubmed: 19497496.

13. Siani A, Accrocca F, Gabrielli R, et al. Is the chimney graft technique a safe and feasible approach to treat urgent aneurysm and pseudoaneurysm of the abdominal aorta? An analysis of our experience and technical considerations. Interact Cardiovasc
Thorac Surg. 2013; 16(5): 692-694, doi: 10.1093/icvts/ivs572, indexed in Pubmed: 23335653.

14. De Bruin JL, Brownrigg JR, Patterson BO, et al. The Endovascular Sealing Device in Combination with Parallel Grafts for Treatment of Juxta/Suprarenal Abdominal Aortic Aneurysms: Short-term Results of a Novel Alternative. Eur J Vasc Endovasc Surg. 2016; 52(4): 458-465, doi: 10.1016/j.ejvs.2016.05.013, indexed in Pubmed: 27527570.

15. May J, White GH, Harris JP. Techniques for surgical conversion of aortic endoprosthesis. Eur J Vasc Endovasc Surg. 1999; 18(4): 284-289, doi: 10.1053/ejvs.1999.0898, indexed in Pubmed: I055026।.

16. Fann JI, Samuels S, Slonim S, et al. Treatment of abdominal aortic anastomotic pseudoaneurysm with percutaneous coil embolization. J Vasc Surg. 2002; 35(4): 8I I-8I4, indexed in Pubmed: 11932686.

17. Nolz R, Gschwendtner M, Jülg G, et al. Anastomotic pseudoaneurysms after surgical reconstruction: outcomes after endovascular repair of symptomatic versus asymptomatic patients. Eur J Radiol. 2012; 81(7): 1589-1594, doi: 10.1016/j. ejrad.2011.04.020, indexed in Pubmed: 21536397.

18. Sachdev U, Baril DT, Morrissey NJ, et al. Endovascular repair of para-anastomotic aortic aneurysms. J Vasc Surg. 2007; 46(4): 636-64I, doi: 10.1016/j.jvs.2007.05.032, indexed in Pubmed: 1776488|.

19. Tsang JS, Naughton PA, Wang TT, et al. Endovascular repair of para-anastomotic aortoiliac aneurysms. Cardiovasc Intervent Radiol. 2009; 32(6): II65-II70, doi: 10.1007/s00270-0099653-0, indexed in Pubmed: 19629588.

20. Matsagas MI, Anagnostopoulos CE, Papakostas JC, et al. Endovascular stent-graft repair as a late secondary procedure after previous aortic grafts. Cardiovasc Intervent Radiol. 2006; 29(4): 655-658, doi: 10.1007/s00270-005-0180-3, indexed in Pubmed: 16502174 .

21. Parodi JC, Ferreira M. Relocation of the iliac artery bifurcation to facilitate endoluminal treatment of abdominal aortic aneurysms. J Endovasc Surg. 1999; 6(4): 342-347, doi: 10.1583/1074-62 18(1999)006<0342:ROTIAB > 2.0.CO;2, indexed in Pubmed: 10893136.

22. Halloul Z, Bürger T, Grote R, et al. Sequential coil embolization of bilateral internal iliac artery aneurysms prior to endovascular abdominal aortic aneurysm repair. J Endovasc Ther. 200I; 8(I): 87-92, doi: $10.1177 / 152660280100800115$, indexed in Pubmed: I 1220476.

23. Donas KP, Pecoraro F, Torsello G, et al. Use of covered chimney stents for pararenal aortic pathologies is safe and feasible with excellent patency and low incidence of endoleaks. J Vasc Surg. 2012; 55(3): 659-665, doi: 10.1016/j.jvs.2011.09.052, indexed in Pubmed: 22169669.

24. Lim CS, Naji Y, Hussain ST, et al. Modified Sandwich-graft Technique Employing Aorfix and Viabahn Stent-grafts to Preserve Hypogastric Flow in Cases of Complex Aortoiliac and Isolated Common Iliac Artery Aneurysms Including the Internal Iliac Artery Ostium. Eur J Vasc Endovasc Surg. 2016; 51 (3): 364-370, doi: 10.1016/j.ejvs.2015.10.008, indexed in Pubmed: 26612599.

25. Antoniou GA, Koutsias S, Antoniou SA, et al. Outcome after endovascular stent graft repair of aortoenteric fistula: A systematic review. J Vasc Surg. 2009; 49(3): 782-789, doi: 10.1016/j. jvs.2008.08.068, indexed in Pubmed: 19028054. 